\title{
Saharan Dust Effects on Human Health: A Challenge for Cuba's Researchers
}

\author{
Silvia J. Venero-Fernández MD MS
}

\begin{abstract}
WHO considers the effects of air pollution one of the most pressing global health priorities. Several years ago, scientists began noting a link between Saharan dust (a meteorological phenomenon that diminishes air quality as it spreads over the globe) and some diseases, but the few studies to date have been inconsistent. Cuba has the human and material resources to study the association between Saharan dust and health. It is important to encourage creation of multidisciplinary research teams to do so.
\end{abstract}

KEYWORDS Health, airborne particulate matter, dust, air pollutants, environmental health, climate, Cuba

\section{INTRODUCTION}

WHO considers the effects of air pollution a pressing global health priority.[1] Environmental pollution from particulate matter is responsible for an estimated $1.4 \%$ of all deaths worldwide.[2] A major component of particulate matter is mineral dust. Dust from the Sahara is the largest contributor to mineral dust in the atmosphere. It is a phenomenon of interest not only for meteorological physics but for public health as well, due to the potential health impact of its atmospheric dispersal and circulation.

Barely two decades ago, the medical science community began to take a greater interest in exploring the health effects of Saharan dust. Finding an important respirable component in Saharan dust has led scientists to link it with cardiovascular disease, asthma, overall mortality and a range of infectious diseases. The evidence is still inconsistent; hence the need for more in-depth studies.[3]

Cuba has human and material resources to examine Saharan dust's health effects and answer some of the related outstanding questions.[4] Lack of awareness of these resources for studying complex phenomena contributes to a relative dearth of research in this area, as do disciplinary compartmentalization and lack of integration in research project development. In response to such shortcomings, this paper aims to describe the impact of Saharan dust on human health, provide information on resources and favorable conditions in Cuba for the research needed, and encourage Cuba's scientific community to collaborate in such an undertaking.

Health impact of Saharan dust In 1830, in the vicinity of the Canary Islands, Charles Darwin noted dust deposits that almost completely covered the ship's deck and interfered with measuring instruments.[5] Once satellites were placed in orbit, scientists were able to detect and measure (even provide images of) aerosols in the atmosphere composed of environmental particulates from the major deserts of Africa and Asia.[6] Remote sensing by the latest generation of satellites has provided an expanded view of the Earth and spawned broad lines of research on dust clouds' health effects.[7]
Dust and sand differ essentially in the size of the particles: particles $<100$ microns in diameter are considered dust and those $\geq 100$ microns are considered sand.[6] Dust clouds that form in desert storms in the Sahara move off the African continent and disperse over the cooler, more humid sea air, reaching altitudes of five to seven $\mathrm{km}$ and spreading thousands of $\mathrm{km}$. They are taken up by the trade winds and carried westward over the Atlantic, reaching the Caribbean Sea in six to seven days and continuing over the Gulf of Mexico.[6]

These clouds have been observed with satellite imaging and the naked eye in several parts of the world, and in Havana since the early 1970s. They sometimes appear as a very heavy fog that cannot be explained by existing meteorological conditions. It is only since the 1990s with new knowledge about the effects of airborne desert dust that they have been accorded their due importance. Dust over Cuba is virtually zero in the winter months (November-April). It increases during the spring, reaching its peak in the summer and diminishing again in the fall.[6]

In recent decades, research has gained momentum that sheds light on the role of air pollution (including dust clouds from desert storms, especially in the Sahara, Sahel, Gobi, and Namib deserts) in weather, climate and health processes.[6]

Dust from these deserts is not identical but made up of different components, which usually commingle during the transoceanic journey before reaching Cuba. The Sahara's aridity makes mineral matter the predominant component of Saharan dust, although it is increasingly contaminated with human and animal waste. In contrast, dust from the Sahel consists largely of aerobiological matter, such as pollen, mites, bacteria and fungi, and contains chemical compounds that can be highly toxic, including insecticides, pesticides, and heavy metals such as mercury.[8] Contrary to what was thought, these agents manage to survive the effects of UV radiation during their long journey, which spans thousands of kilometers in the middle troposphere.[6]

Based on epidemiological studies up to 2011 in Europa, Asia, and the Caribbean, the technical report of the European Topic Centre on Air Pollution and Climate Change Mitigation reached three conclusions:

- There are few studies on the potential effects of dust intrusions.

- No association has been demonstrated between the fine particles in Saharan dust and day-to-day mortality.

- The association between large particulates $\left(\mathrm{PM}_{10}\right.$ and $\mathrm{PM}_{2.5}-$ $\mathrm{PM}_{10}$ ) and mortality is controversial.[3]

The report also noted that limitations and lack of homogeneity among studies contribute to persistent uncertainty: differences in fraction size, determination of particulate concentrations, time periods studied (for example, heat waves), and definitions of dust days. The number of dust days is low, which limits statis- 
tical power to establish specific causal relationships between dust presence and mortality.[3]

Basic studies have shown a carcinogenic effect of certain metals (copper, chromium, mercury, nickel) found in Saharan dust.[9,10]

In Puerto Rico, in vitro studies have shown that traces of watersoluble metals in $\mathrm{PM}_{2.5}$ particles in Saharan dust, together with levels of bacterial endotoxins are a major determinant of cytotoxicity in lung cells, and may trigger an adverse response to respirable particulate matter in susceptible or predisposed individuals.[11]

Existing resources and their global use Tele-epidemiology has proven a fundamental auxiliary tool in health surveillance, making it possible to record and map atmospheric phenomena on a circumpolar scale through remote sensors, generate spatial statistics and study associations between such phenomena and disease. Forecast maps and early alerts provided by teleepidemiology have informed decision-making for health policy and resource management in disease prevention and control.[12]

Use of these resources has enabled African countries to examine their epidemiological situation and determine the association between dust storms and bronchial asthma, meningitis, and gastrointestinal diseases, which increasingly cast a shadow over the continent's public health landscape.[6] Between January and May 2012, Senegal recorded an increase in meningitis cases at the same time as high concentrations of Saharan dust.[13]

Furthermore, several studies have shown a relationship between the presence of these desert dust clouds and diseases in marine ecosystems. For example, a 2005 study on the Pacific coast of the southern US states revealed that the sea bed was seriously compromised by the presence of Aspergillus sydowii, putting these ecosystems and their interaction with human activity in jeopardy.[14]

\section{CUBAN EXPERIENCE}

A Cuban study by the Meteorology Institute and the Pedro Kouri Tropical Medicine Institute explored the potential association between the arrival of dust clouds and health problems. Some of the main findings were that the viruses that caused acute respiratory infections and acute diarrheal disease were sensitive to weather variations and high dust concentrations; that diseases can manifest after delays of one to three months, and that outbreaks of acute diarrheal disease coincided with the presence of Saharan dust, low precipitation and low humidity. According to the study's author, the findings, while valuable, should be viewed with caution. They indicate a series of associations and coincidence with epidemics in Cuba, but there is no information at this time about which viruses were present before, during or after the appearance of the Saharan dust cloud.[15] This is a research topic to revisit once we know more about the climatology of dust over Cuba and have identified the periods of greatest risk.

Another important finding noted by Eugenio Mojena López at the National Symposium of the Saharan Dust Project in October 2013 was the highly significant association between days with high dust concentrations and the aerosol index, marked by an increase in acute respiratory infections and asthma in Cuba's western and eastern provinces (Pinar del Río and Guantánamo).[16]

Cuba has several resources available to tackle the related questions. One is the new aerobiological station in Havana, whose findings are released by the University of Havana Biology Faculty to inform epidemiological and clinical studies. An example of the station's findings is the detection of multiple fungal species in periods of Saharan dust intrusions.[17] Second, the environmental monitoring station at the National Hygiene, Epidemiology and Microbiology Institute (INHEM), has contributed to identification of particulate and mineral matter associated with dust periods. [18] Finally, INHEM's toxicology department, the National Medical Genetics Center (which contributes to epigenetic studies) and nanotechnology resources can also be used for studies in this little-explored field.[19,20]

\section{CHAШENGES AND OPPORTUNITIES}

Basic etiological questions that could be addressed through multidisciplinary studies include:

- For a given disease or group of diseases, what is the impact of Saharan dust events on prevalence, incidence, mortality, emergency room visits and hospitalizations?

- What risks to population health are posed by large particles, nanoparticles, and other chemical and biological components of Saharan dust?

- To what extent will the continued presence of dust contribute to epigenetic changes and eventual damage to health over the coming years?

A research agenda to address these questions is an urgent imperative. The existence of resources that could be more thoroughly exploited to shed light on the health impact of Saharan dust leads us to call on Cuba's scientific community to forge multidisciplinary partnerships and contribute our findings to better knowledge in this field. $-1 /$ -

\section{REFERENCES}

1. World Health Organization [Internet]. Geneva: World Health Organization; c2016. Programmes. The world health report. Chapter 4, Environmental risks; 2002 [cited 2014 Dec 12]. Available from: http://www.who.int/whr/2002/chapter4/en/ index7.html

2. Cohen AJ, Anderson HR, Ostro B, Pandey KD, Kryzanowsky $\mathrm{M}$, Kuenzly $\mathrm{N}$, et al. Mortality impacts of urban air pollution. In: Ezzati M, Lopez AD, Rodgers A, Murray CJL, editors. Comparative Quantification of Health Risks: Global and Regional Burden of Disease Attributable to Selected Major Risk Factors. Geneva: World Health Organization; 2003.
3. The European Topic Centre on Air Pollution and Climate Change Mitigation [Internet]. Bilthoven (NL): ETC/ACM; c2016 [cited 2015 Oct 23]. Health effects from Sahara dust particles; [updated 2016 May 31]; [cited 2015 Oct 23]. Available from: http://acm.eionet.europa.eu/

4. Lecha Estela LB, de Carvajal EC, Estrada Moreno A, Gómez Acosta EC. Pronósticos biometeorológicos: vía para reducir la ocurrencia de crisis de salud. Caso Sagua La Grande. Rev Cubana Salud Pública [Internet]. 2008 Jan-Mar [cited 2016 Mar 23];34(1). Available from: http://scielo .sld.cu/scielo.php?script=sci_arttext\&pid=S0864 $-34662008000100009 \&$ Ing=es. Spanish.
5. Darwin C. An account of the fine dust which often falls on vessels in the Atlantic Ocean. Quarterly J Geological Soc London. 1845;2:26-30.

6. Mojena E, Ortíz Bultó P, Ortega González A, Rivero Valencia A. Tormentas de Polvo del Sahara. Su impacto en el Atlántico, Mar Caribe y el Golfo de México. Rev Cubana Meteorol. 2006;13(1):99-100. Spanish.

7. Beck LR, Bradley MS, Byron MW. Remote sensing and human health: new sensors and new opportunities. Emerg Infect Diseases [Internet]. 2000 May-Jun [cited 2016 Jan 5];6(3):217-27. Available from: http://www.ncbi.nlm.nih.gov/ pubmed/10827111 
8. Griffin DW. Atmospheric movement of microorganisms in clouds of desert dust and implications for human health. Clin Microbiol Rev. 2007 Jul;459-77.

9. Hernández-Franco $P$, Valverde $M$, Rojas $E$. Los metales como inhibidores del sistema de reparación del ADN. Rev Esp Cienc Quím Biol. 2009:12(2):75-82. Spanish.

10. Bhattacharyya D, Boulden AM, Foote RS, Mitra $S$. Effect of polyvalent metal ions on the reactivity of human O6-methylguanine-DNA methyltransferase. Carcinogenesis. 1998 Apr;9(4):683-5.

11. Rodríguez-Cotto RI, Ortiz-Martínez MG, Rivera-Ramírez E, Méndez LB, Dávila JC, Jiménez-Vélez BD. African dust storms reaching Puerto Rican coast stimulate the secretion of IL-6 and IL-8 and cause cytotoxicity to human bronchial epithelial cells (BEAS-2B). Health. 2013;5(10A2):14-28.

12. Rodríguez-Morales AJ. Ecoepidemiología y epidemiología satelital: nuevas herramientas en el manejo de problemas en salud pública. Rev Perú Med Exp Salud Pública. 2005 JanMar;22(1):54-63. Spanish.

13. Diokhane AM, Jenkins GS, Manga N, Drame MS, Mbodji B. Linkages between observed, modeled Saharan dust loading and meningitis in Senegal during 2012 and 2013. Int J Biometeorol. 2016 Apr;60(4):557-75.
14. Garrison VH. From Aspergillus to Timbuktu: African Dust, Coral Reefs and Human Health [Internet]. Philadelphia: International Union of Soil Sciences; 2016 [cited 2016 Mar 23]. Available from: https://crops.confex.com/crops/wc20 06/techprogram/P14057.HTM

15. Ortíz Bultó $P L$, Pérez Rodríguez $A E$, Rivero Valencia A, Pérez Carreras A, Cangas JR, Lecha Estela LB. La variabilidad y el cambio climático en Cuba: potenciales impactos en la salud humana. Rev Cubana Salud Pública [Internet]. 2008 Mar [cited 2016 Mar 23];34(1). Available from: http://www.scielosp.org/scielo .php?script=sci_arttext\&pid=S0864-34662008 000100008\&lng=en. Spanish.

16. Mojena López E, Ortega González A, Casilles Vega EF, Leyva Santos J. Tormentas de polvo del Sahara: Su presencia en Cuba. Rev Cubana Meteorol [Internet]. 2015 [cited 2016 Mar 23]:21(1):120-34. Available from: http://www .met.inf.cu/contenidos/biblioteca/revistas/2015/ n $1 / 9-$ Nubes $\% 20$ de $\% 20$ polvo $\% 20$ del $\% 20$ Sahara.\%20Su\%20presencia\%20en\%20Cuba .pdf. Spanish.

17. Almaguer M, Aira MJ, Rodríguez-Rajo FJ, Rojas TI. Temporal dynamics of airborne fungi in Havana (Cuba) during dry and rainy seasons: influence of meteorological parameters. Int $\mathrm{J}$ Biometeorol. 2014 Sep;58(7):1459-70.
18. Piñera I, Pérez G, Aldape F, Flores MJ, Molina E, Ramos M, et al. Estudio de partículas finas de la atmósfera en Centro Habana. Contrib Educ Prot Med Amb. 2010;9:E39-E47. Spanish.

19. Durham TR, Snow ET. Metal ions and carcinogenesis. EXS. 2006;(96):97-130.

20. Gutiérrez-González L, Hernández -Jiménez MJ, Molina-Borchert L. Daños para la salud tras exposición laboral a nanopartículas. Med Segur Trab. 2013 Apr-Jun;59(231):276-96. Spanish.

\section{THE AUTHOR}

Silvia J. Venero-Fernández (silviavf@inhem .sld.cu), epidemiologist, National Hygiene Epidemiology and Microbiology Institute, Havana, Cuba.

Submitted: July 17, 2015

Approved for publication: April 13, 2016

Disclosures: None

\section{International Congress:
Controlling Diabetes
and its More Severe Complications

\author{
December 7-9, 2016 \\ Convention Center Plaza America \\ Varadero, Matanzas, Cuba
}

\section{Main Topics:}

- Diabetes prevention

- Role of growth factors in regulating wound healing

- Diabetic foot ulcers

- Practical experiences in use of human recombinant epidermal growth factor to treat complex diabetic foot ulcers

- Implementation of diabetes control programs

- Role of primary, secondary and tertiary health care in comprehensive care of diabetic foot ulcers

- Comprehensive care to assure safe pregnancy in diabetic women

- New developments in diabetes control

- Postmarketing pharmacosurveillance of Heberprot-P in the Cuban health system

\section{Contact: http://hptcongress.cigb.edu.cu/index.php/en}

